\title{
THE EMOTIONAL WORK OR EMOTIONS AT WORK: A STUDY ABOUT THE DEMANDS OF EMOTIONAL LABOR AMONG UNIVERSITY TEACHERS IN PUNJAB
}

\author{
Azka Murtaza \\ PhD Scholar, Department of Sociology \& Criminology, University of Sargodha \\ Azka.qazi@yahoo.com \\ Yasir Nawaz Manj \\ Chairman, Department of Sociology \& Criminology, University of Sargodha. \\ Yasir.manj@gmail.com \\ Ayesha Siddiqa \\ PhD Scholar, Department of Sociology \& Criminology, University of Sargodha. \\ Ayesha.siddiqa84@gmail.com
}

\begin{abstract}
Teaching is based on face-to-face interaction and teachers are required to show certain emotions and suppress others in order to teach their students well and motivate them. The present study was aimed to find out the nature and extent of the emotional labor among university teachers. The universe of the study was Universities from Punjab, Province \& multistage sampling technique was used for the selection of the Universities as well as for the respondents. At $1^{\text {st }}$ stage, three universities i.e., University of Sargodha, PMAS-Arid Agriculture University Rawalpindi and University of Lahore were selected randomly. At second stage, the faculties and departments were selected randomly and at third stage the respondents were selected conveniently. The sample size was comprised of 120 respondents. The data was analyzed by the help of statistical software SPSS and descriptive statistic was applied (Frequencies, Percentages, mean and Std. Deviation values), whereas, Correlation and ANOVA test was applied for hypotheses testing. Results showed that teachers do the surface acting for managing their personal emotions at the workplace. Their job demands to express the positive emotions and hide the negative emotions. The emotional labor is directly influencing the personal wellbeing of the teachers and their work productivity and sometime, may leads toward the condition of emotional exhaustion.
\end{abstract}

Keywords: Emotional labor, Surface Acting, Deep acting, Display rules, Job performance, Job Satisfaction.

\section{INTRODUCTION}

Gosserand \& Diefendorff, (2005) has defined emotional labor as modifying and adjusting the emotional displays in order to attain the goals required for work and basis behind this is to dictate the emotions the emotions for achieving the goals at workplace. It entailed a firm contrast between the how one displays his or her emotions and what are the institutionalized display rules. The strategies of surface acting and deep acting are adopted by maintaining the constancy between the display and display rules. A study revealed that the behavior and the feeling $\mathrm{s}$ of the employees are affected differently within and outside the work environment. The gap between the personal and professional emotions is linked with the emotional well-being as only the managed professional emotional emotions are accepted at the workplace (Brief \& Weiss, 2002).

There are the considerable impacts of the massif-cation and commercialization of education on any county's economy; but it pertains certain challenges to the education institutions (Krishnan \& Priah, 2017). The higher education across the worldwide has been restructured from purely social welfare to the market principles (Arokiasamy, 2011). It turned the universities as service institutions and students are perceived as the customer (Berry and Cassidy, 2013). The commercialization of the education has changed the job characteristics and the role of a teacher apart from his or her profession. A university teacher is expected to satisfy the students, maintaining his evaluation rating 
done by the students and more production (graduate students) by doing the required emotional labor (Hall et al., 2013).

Emotional labor is the process of regulating the emotions and managing the display rules associated with the workplace requirements. The concepts of emotional regulations and the display rules at workplace are highly interlinked with the concepts of emotional labor as they serve as the principles for the appropriate expression of the emotions (Hochschild, 1983). The relationship with the employees and the customers is very exigent and required empathetic understanding and emotional concern and focusing on not treating the people like objects at the workplace (Zapf et al., 1999).

The relationship of a university lecturer and student is directly linked with the overall performance of the university as this relationship is considered as the relationship between the employees and customers because the service is based on profit chain. The good relationship with the customers (students) will enhance the Universities overall performance (Heskett et al., 1997). Constanti and Gibbs, (2004) also found that university performance is linked with the service which is provided by the employees to the students. So, universities are strongly needed to satisfy the students in a manner to get more competitive advantage. Consequently, the student's satisfaction, performance and retention are affected by university teacher's wellbeing, job satisfaction and teacher's job performance and can be considered as the predictive factors of the level of job satisfaction and the level of emotional labor level. The customer driven system avows that teacher perform the emotional labor by diminishing the negative emotions and avoiding dissatisfy the customers (Selvarajah \& Sulaiman, 2014). The demands made by customers, management and workload leads to exploitation of academicians and consequently to stress (Gaan, 2012).

The people use varying degrees of their selves for performing their roles and maintain the integrity between who they are and what the role they possess and it leads toward the attachment and the detachment of the roles (Kahn, 1990). The emotional labor has two significant dimensions named as surface acting and the deep acting. The surface acting refers to faking the demanded emotions by hiding the personal emotions whereas deep acting refers to the modification of the feelings for displaying the appropriate emotions demanded by the work (Grandey, 2000). It is associated with self-estrangement because an employee totally ignores his or her personal feelings and roles and became estranged (Hayes \& Kleiner, 2001) Depressed, alienated, exhaustion and loss their identity (Schaubroeck \& Jones, 2000; Zapf, 2002).

There is a face-to-face interaction in student teacher relationship and teachers have to pay great effort for motivating and encouraging the students. These aspects of the teaching profession demand to show particular emotions and suppress other personal emotions (Ogbonna \& Harris, 2004; Ybema \& Smulders, 2002) which sometime leads toward the state of emotional exhaustion (Maslach, Schaufeli, \& Leiter 2001). The emotional work demand can be considered as the predicted of burnout and it is found in previous research that the frequency of interaction leads toward the overload and burnout. (Cordes \& Dougherty, 1993; Maslach, 1978). Emotional labor is an important factor required for good job performance (Robbins \& Judge, 2012). It can be considered as an important criterion to evaluate the levels of achieving the job demanding goals (Özdevecioğlu \& Kanıür, 2009).

The emotional regulation describes what emotions have the employees, when they have them, how they experience them and when they express such emotions (Gross, 1998). There are several display rules e.g., not showing the fear and anxiety in front of students or customers. An earlier study found that teaching profession demands emotional labor, which involves emotional understanding and emotional practice (Hargreaves, 1998, 2000, 2001).

\section{The conceptual Understanding of the Emotional labor}

The emotions are the central part of the work and they are considered as the intra- psychic states that are influence by the variety of factors i.e., work environment, relationship with authority figures and other employees, nature of job, work stress, and job satisfaction. These are the predictor of emotions at workplace. These emotions play a significant role in the outcomes of the work on employees and the organization as well and needed to manage at the workplace. The emotional labor is a process that refers to the management of the emotions at the workplace as per the requirement of the job. There are certain display rules that distinguish about which emotions are needs to display and which emotions are needed to hide at the job. These display rules and the dimensions of the emotional labor 
are surface acting, deep acting, emotional exhaustion, job performance and satisfaction; which are the predictors of self-estrangement and work productivity (Hochschild, 1983; Hayes \& Kleiner, 2001; Gosserand \& Diefendorff, 2005). The present study aimed to find out the nature and extent of the emotional labor among university teachers in orientation with its multiple strategic Dimensions. The concept "Emotional labor" in the study is the manipulation of the personal feelings and displaying the fake emotions demanded by the job for better work productivity among university teachers to enhance the student's capabilities in a positive manner.

\section{Research Objectives}

The study was aimed;

1. To find out the nature and extent of the emotional labor among university teachers.

2. To acknowledge the strategies of emotional labor.

3. To investigate the relationship between emotional labor and emotional exhaustion.

4. To acknowledge the consequence of the emotional labor on personal and professional development of the teachers.

\section{Research Hypotheses}

1. There is a significant positive relationship between emotional labor and Surface acting.

2. There is a positive relationship between intrinsic motivation for job performance and surface acting.

3. There is a positive relationship between surface acting and emotional exhaustion.

4. There is a positive relationship between emotional exhaustion and intrinsic motivation for the job performance.

5. There is effect of experience levels on the intrinsic motivation for emotional labor.

6. There is effect of educational level on emotional management.

\section{REVIEW OF LITERATURE}

The term emotional labor refers to the state of managing the emotions for creating and maintaining the impression noticeable by others. He divided the professionalism into two groups as the one who is using the emotional labor and the other who is not using the emotional labor. For doing emotional labor, there are three possible ways to use the emotional labor. There should be some ways of interaction between employees and customers. Secondly, the employees have to keep the customers emotion at their greater preferences. Thirdly, there must be management's control over the interactions of employees and customers. The emotional labor can be done by the three ways of acting and which are surface, deep and genuine. When employees change and modify their external expressions by hiding the personal emotions or not needed to be felt privately at the workplace, they are called the surface acting of the employees. The second technique or the way of emotional labor is deep acting which refers to the state in which employees not only have to modify their external emotions but internal feelings also. The genuine acting is a technique in which the felt emotions are similar to the expressed emotions. (Hochschild, 1983).

Brotheridge and Grandey (2002) introduced the difference between the job-focused emotional labor and employee-focused emotional labor. The job-focused emotional labor are the perceived emotional requirements for the demand of job whereas employee-focused emotional labor is the managing the emotions and the expressions at the workplace.

There are very limited researches on the emotional labor of university teachers. The teaching profession is considered as the extremely emotional. The lecturers have a distinct array of obligations for performing their job i.e., teaching, research, administration and management as well as students character building which require a varying degree of emotional displays with the changing circumstances. (Kinmann et al., 2011; Ogbonna \& Harris, 2004)

Gann, (2012) argued that there is significant change in the educational paradigm with greater focus on efficiency, quality, effectiveness and predictability. It also changed the role of teachers as a service provider and they treat the students as a customer. The academician is aimed to get excellent rating with continue tenure and research funding. It is also found in others studies that this transition in the role performance leads toward the distinct demands for the job within role theory paradigm. It is highly linked with the emotions that are actually felt and those that are expressed in the front of students and that become the cause of the emotional labor (Morris \& Feldman, 1996; Varca, 2009). 
Lawrence and Sharma, (2002) explained that the teacher's evaluation by the students is also a very strong contributor of the co-modification of the education. The students are considered the consumers in the educational institution, and they have the right to evaluate the service they receive. The results indicate that there is strong relationship between the need of friendly behavior and the student's doing good evaluation. It links with the good rating and the teacher's friendly behavior to please their students as a marginal tool. The people with higher position do lesser the emotional labor because employees with higher autonomy decide what and how to respond to the demand s of their job. There is also relationship with higher qualification and emotional labor, as the respondents with $\mathrm{PhD}$ degree show less emotional labor but emotional labor is experienced in all age group both young and old (Bakker et al., 2005). It is found that the higher the experience, the less the surface acting and more deep acting (Wharton, 1993). The greater emotional labor is negatively impacted on the person's personal wellbeing and may lead toward the condition of emotional exhaustion (Karim, 2009).

Grandey (2000) stated that emotional labor is linked with the job satisfaction. It is also found in study that surface acting i.e., emotional dissonance is linked with the lower wellbeing i.e., emotional exhaustion than the deep acting (Brotheridge \& Grandey, 2002; Kim, 2008). One study resulted as that hiding the personal negative emotions leads toward the state of emotional exhaustion or burnout and displaying positive as well as the negative emotions show the less signs of emotional exhaustion or the condition of burnout (Montgomery et al., 2006). The teachers are not supported or trained to manage their emotions at the workplace (Nias, 1999).

Mann (1999) found that all the service-oriented jobs demand the emotional labor. Emotional labor is the condition that subsists when the experienced emotions are different than the displayed emotions. The displaying the positive emotions at workplace are directly linked with the positive evaluation of the service quality by customers. It is the management of the roles and the tasks for the job requirement (Constanti \& Gibbs, 2004).

Emotional labor is the condition of displaying the suitable emotions. The display rules deal with the tactics that which emotions are needed to hide or show at the workplace (Ashforth \& Humphrey, 1993). Sometime deep acting can result the positive organizational outcomes (Shani et al., 2014). It is found that surface acting and deep acting both are linked with the individual wellbeing. The surface acting is more negatively impacted on the individual's wellbeing as well as outcome i.e., low job satisfaction and poor service quality because it is more difficult than deep acting (Lam \& Chen, 2012). Deep acting required the more effort to perform and it is linked with the less personal damage as it reduces the emotional dissonance (Grandey, 2000).

\section{RESEARCH METHODOLOGY}

The present research was quantitative and descriptive in nature. The Universe of the research was the teachers from Punjab, Province. The multistage sampling technique has been used in this study to find out the nature and the extent of the emotional labor among University Teachers. At $1^{\text {st }}$ stage, University of Sargodha, PMAS- Arid Agriculture University Rawalpindi and University of Lahore were selected by using simple random sampling technique. At $2^{\text {nd }}$ Stage, the faculties and departments were selected randomly and at $3^{\text {rd }}$ stage, the convenient sampling technique was applied for the selection of the respondents from these universities. As the respondents were teachers from the universities, who remain busy in tough long work schedule. So, this technique was useful for the selection of respondents, who were conveniently available to respond in the study. The used techniques helped the researcher to gather information within less time and little resources. The sample size was comprised of 120 respondents. A questionnaire by the help of existing measurement scale and available literature was developed to gather the data. The data was analyzed by using statistical software of data analysis (SPSS) by using statistical techniques i.e., descriptive statistics i.e., frequencies, percentages, mean and Std. deviation values to analyze the data. The correlation and ANOVA test was applied for hypotheses testing. 
ANALYSIS \& RESULTS

Table No. 1 Descriptive Statistics

Demographic Variables Age

$\begin{array}{ccc}21 \text { to } 30 & 51 & 42.5 \\ 31 \text { to } 40 & 43 & 35.8 \\ 41 \text { to } 50 & 18 & 15.0 \\ 50 \text { and above } & 8 & 6.7\end{array}$

Mean=1.8583, Std. Deviation $=\mathbf{. 9 1 0 2 2}$

$\begin{array}{lll}\text { Gender } & & \\ \text { Male } & 68 & 56.7 \\ \text { Female } & 52 & 43.3\end{array}$

Mean $=\mathbf{1 . 4 3 3 3}$, Std. . Deviation $=\mathbf{. 4 9 7 6 1}$

\section{Education}

M.A / M.Sc/ BS hons.

$18-15.0$

M.Phil/ MS

$60 \quad 50.0$

$\begin{array}{lll}\mathrm{PhD} & 40 & 33.3\end{array}$

Post Doc

2

1.7

Mean=2.2167, Std. Deviation $=.71224$

\section{Marital Status}

$\begin{array}{ccc}\text { Single } & 49 & 40.8 \\ \text { Married } & 71 & 59.2\end{array}$

Mean $=1.5917$, Std . Deviation $=.49359$

\section{Experience}

1 Year to 5 Year

6 Year to 10 Year

66

55.0

11 Year to 15 Year

26

21.7

16 Year and above

Mean $=1.7917$, Std. Deviation $=1.03628$

\section{Total}

120

100

The results revealed that $42.5 \%$ respondents were from $21-30$ age group. The age group 31 to 40 was $35.8 \%$ and 41 to 50 were $15 \%$ whereas 51 and above group was $6.7 \%$. The data about gender group showed that $56.7 \%$ were male respondents whereas $43.3 \%$ were female respondents. The $15 \%$ respondents had master degree or equal qualification whereas half about $50 \%$ respondents had the M.Phil. degree or equal qualification. A significant proportion as $33.3 \%$ respondents had $\mathrm{PhD}$ degree and only $1.7 \%$ respondents had the degree of post-Doc. The results indicated that $40.8 \%$ respondents were single, whereas $59.2 \%$ respondents were married.

It is found that more than half population as about $55 \%$ were not much experience as they had only 1 to 5 year of teaching experience. $21.7 \%$ had 6 to 10 years of teaching experience whereas, $12.5 \%$ had up to 15 years of experience. Only $10.8 \%$ respondents had greater experience as having more than 16 year of teaching experience.

Table No. 2 Mean and Standard Deviation of emotional labor and sub indicators of display rules

Indicator IDVs

Emotional labor DVs

\section{Surface Acting}

Genuine Acting

Emotional

Dissonance

Job satisfaction

Emotional

Exhaustion

$\mathbf{N}$

Mean

32.7250

11.3167

13.4500

9.9750

14.5750

10.3250
Std. Deviation

8.90846

5.77280

5.13099

3.34479

2.37339 
$\begin{array}{lll}\text { Emotional } & 120 & 12.9333\end{array}$

The above indicators are taken from the above review of literature and used to find out the emotional labor among university teachers. The mean value of emotional labor is 32.7250 and Std. deviation is 8.90846 which are significantly different from all other dependent variables. The mean value of surface acting is 11.3167 and genuine acting is 13.4500 , while Std. Deviation is 2.92478 and 5.77280 respectively, which are significantly different from each other, but the mean value of emotional dissonance is 9.9750 and its Std. Deviation is 5.13099. The mean and Std. Deviation of emotional exhaustion is 10.3250 and 2.37339; which are significantly different from the mean of job satisfaction and emotional deviance, which is 14.5750 and 12.9333 with 3.34479 and 4.06819 respectively.

Table No. 3 Major findings

\begin{tabular}{|c|c|c|c|c|c|c|}
\hline \multirow[t]{2}{*}{ Statement } & \multicolumn{2}{|r|}{ Agree } & \multicolumn{2}{|r|}{ Neutral } & \multicolumn{2}{|c|}{ Disagree } \\
\hline & $F$ & Percentage & $F$ & Percentage & $F$ & Percentage \\
\hline $\begin{array}{l}\text { Teachers play a significant role in the } \\
\text { character building of the students. }\end{array}$ & 114 & $95 \%$ & 6 & $5 \%$ & 0 & $0 \%$ \\
\hline $\begin{array}{l}\text { If you are upset or distress, your job } \\
\text { demands to hide your emotions in the } \\
\text { class room. }\end{array}$ & 107 & $89.2 \%$ & 9 & $7.5 \%$ & 4 & $3.3 \%$ \\
\hline $\begin{array}{l}\text { You work hard to manage your } \\
\text { emotions as per the requirement of } \\
\text { workplace. }\end{array}$ & 72 & $60 \%$ & 33 & $27.5 \%$ & 15 & $12.5 \%$ \\
\hline $\begin{array}{l}\text { You neglect your personal feelings } \\
\text { while focusing on the productivity of } \\
\text { work. }\end{array}$ & 92 & $76.7 \%$ & 19 & $15.8 \%$ & 9 & $7.5 \%$ \\
\hline $\begin{array}{l}\text { The difference between personal } \\
\text { feelings and expressed emotions } \\
\text { leads toward the exploitation of } \\
\text { personal wellbeing. }\end{array}$ & 76 & $63.3 \%$ & 32 & 26.7 & 12 & $10 \%$ \\
\hline $\begin{array}{l}\text { You manage your emotions at the } \\
\text { workplace for greater job } \\
\text { satisfaction. }\end{array}$ & 91 & $75.8 \%$ & 13 & $10.8 \%$ & 16 & $13.3 \%$ \\
\hline $\begin{array}{l}\text { Greater suppression of personal } \\
\text { emotions leads toward the emotional }\end{array}$ & 98 & $81.7 \%$ & 19 & $15.8 \%$ & 3 & $2.5 \%$ \\
\hline
\end{tabular}

Gemotional

The gathered data revealed that majority i.e., $95 \%$ respondents were agreed that teachers play a significant role in the character building of the students. The majority of $89.2 \%$ were agreed with the statement that "If you are upset or distress, your job demands to hide your emotions in the class room." The $60 \%$ respondents were agreed that they work hard to manage their emotions as per the requirement of workplace. The majority i.e., $76.7 \%$ respondents were agreed that they neglect their personal feelings while focusing on the work productivity. The majority i.e., $63.3 \%$ were agreed that the difference between personal feelings and expressed emotions leads toward the exploitation of personal wellbeing and $75.8 \%$ were agreed that they manage their emotions at the workplace for greater job satisfaction. The majority i.e., $81.7 \%$ were agreed that greater suppression of personal emotions leads toward the emotional exhaustion.

\section{Bivariate Analysis}

H1: There is a significant positive relationship between emotional labor and Surface acting.

H2: There is a positive relationship between intrinsic motivation for job performance and surface acting.

H3: There is a positive relationship between surface acting and emotional exhaustion.

H4: There is a positive relationship between emotional exhaustion and intrinsic motivation for the job performance. 
In case of hypothesis 2, Pearson correlation was applied to determine the relationship between intrinsic motivation for job performance and Surface acting. There is a strong, positive correlation between "intrinsic motivation for job performance" and "Surface acting" and that is statistically significant $\left(\mathrm{r}=.382^{* *}, \mathrm{~N}=120, \mathrm{p}=.000\right)$. So, the hypothesis $\mathrm{H} 2$ "There is a positive relationship between intrinsic motivation for job performance and surface acting" is accepted.

Table No. 4 Correlation Matrix

\begin{tabular}{lccccc}
\hline & & 1 & 2 & 3 & 4 \\
\hline Emotional Labor & & - & & \\
& & & & \\
Surface Acting & Pearson Correlation & $.374^{* *}$ & & \\
& Sig. (2-tailed) & .000 & & \\
Intrinsic Motivation for & $\mathrm{N}$ & 120 & & \\
The job performance & Pearson Correlation & .014 & $.382^{* *}$ & \\
& Sig. (2-tailed) & .876 & .000 & \\
Emotional Exhaustion & $\mathrm{N}$ & 120 & 120 & \\
& Pearson Correlation & .089 & $.274^{* *}$ & $.426^{* *}$ & - \\
& Sig. (2-tailed) & .334 & .002 & .000 & \\
\hline
\end{tabular}

The hypothesis 1,2,3, and 4 are presented by the correlation matrix and results revealed that a Pearson correlation was applied to determine the relationship between emotional labor and surface acting. There is a positive, strong correlation between the emotional labor and surface acting, which is statistically significant $\left(\mathrm{r}=.374^{* *}, \mathrm{p}=.000, \mathrm{~N}=120\right)$. So, the hypothesis $\mathrm{H} 1$ "There is a significant positive relationship between emotional labor and Surface acting" is accepted.

In case of Hypothesis 3, Pearson correlation was run to determine the relationship between Surface acting and emotional exhaustion. There is a strong, positive correlation between "Surface Acting" and "Emotional Exhaustion" and that is statistically significant $\left(\mathrm{r}=.274^{* *}, \mathrm{~N}=120, \mathrm{p}=.002\right)$. So, the hypothesis $\mathrm{H} 3$ "There is a positive relationship between surface acting and emotional exhaustion" is accepted.

In case of hypothesis 4, a Pearson correlation was applied to determine the relationship between Emotional Exhaustion and intrinsic motivation for the job performance. There is a strong, positive correlation between emotional exhaustion and intrinsic motivation for job performance and that is statistically significant $(\mathrm{r}=.426, \mathrm{~N}=120, \mathrm{p}=.000)$. So, the hypothesis 4 "There is a positive relationship between emotional exhaustion and intrinsic motivation for the job performance" is also accepted.

H5: There is an effect of experience levels on the intrinsic motivation for emotional labor.

Table No. 5: ANOVA

\begin{tabular}{cccrrr} 
& Dependent Variable & df & Mean Square & F & Sig. \\
\hline Experience & $\begin{array}{c}\text { Intrinsic Motivation } \\
\text { for Emotional Labor }\end{array}$ & 3 & 57.513 & 5.757 & .001 \\
\hline
\end{tabular}

Table 5 presents the results of Univariate ANOVA that was conducted in order to explore the effect of experience level (which is independent Variable) on the intrinsic motivation for emotional labor (The dependent Variable). The result indicated that there is statistically significant difference between the experience levels of the respondents in term to score on intrinsic motivation for emotional labor $(\mathrm{p}=.001)$ with $\mathrm{F}=5.757$, which show that Hypothesis 5 was supported and accepted.

Table No. 6: ANOVA

H6: There is an effect of educational level on emotional management.

\begin{tabular}{lcrrrr} 
& Dependent Variable & Df & Mean Square & \multicolumn{1}{c}{ F } & Sig. \\
\hline Educational Level & $\begin{array}{c}\text { Emotional } \\
\text { Management }\end{array}$ & 3 & 1137.442 & 25.518 & .000 \\
\hline
\end{tabular}

Table 6 presents the results of ANOVA that illustrate in order to find out the effect of educational level (Independent Variable) on the emotional management. The results showed that there is statistically significant difference between the educational levels of the respondents in term to score 
on emotional management. The $\mathrm{P}=.000$ with $\mathrm{F}$ value $=25.518$, which show that hypothesis 6 was supported and accepted.

\section{CONCLUSION}

It is concluded that teachers do the motional labor by hiding and suppressing their actual emotions. There are several dimensions of the emotional labor i.e., surface acting, deep acting, genuine acting, intrinsic motivation for good job performance and emotional exhaustion. The teaching profession demands to manage the emotions in front of students because teachers play a significant role in the character building of the students. It demands to express the positive emotions and hide the negative emotions i.e., distress, angry, or upset etc. and it need a great effort for managing the emotions by neglecting the personal emotions and expressing the fake emotions. This display rule is linked with the work productivity as well as the job satisfaction level. But it negatively influences the personal well beings of the teachers and may leads toward the state of emotional exhaustion or burnout. If a teacher cannot hide his personal feelings and emotions in front of class, it may negatively influence the students as well as the work productivity because teaching profession demands to motivate and encourage the students with positivity.

\section{REFERENCES}

Arokiasamy, Anantha Raj A. (2011). "An Analysis of Globalization and Higher Education in Malaysia", Australian Journal of Business and Management Research, 1(9), 73-81.

Ashforth, B. E., \& Humphrey, R. H. (1993). Emotional labor in service roles: The influence of identity. Academy of Management Review, 18(1), 88-115.

Bakker, A. B., Demerouti, E., \& Euwema, M. C. (2005). "Job resources buffer the impact of job demands on burnout". J. Occupational. Health Psychology, 10, 170-80.

Berry, K., \& Cassidy, S. (2013), "Emotional Labour in University Lecturers: Considerations for Higher Education Institutions", Journal of Curriculum and Teaching, 2, 22-36.

Best, R. G., Downey, R. G., \& Jones, R. G. (1997, April). Incumbent perceptions of emotional work requirements. Paper presented at the12th annual conference of the Society for Industrial and Organizational Psychology, St. Louis, MO.

Brief, A. P., \& Weiss, H. M. (2002). Organizational behaviour: Affect in the workplace. Annual Review of Psychology, 53, 279-307.

Brotheridge, C. M., \& Lee, R. T. (1998). On the dimensionality of emotional labour: Development and validation of the Emotional Labour Scale. Paper presented at the First Conference on Emotions in Organizational Life, San Diego.

Brotheridge, C., \& A. Grandey. 2002. Emotional labor and burnout: Comparing two perspectives on "People work". Journal of Vocational Behavior 60 (1),17-39.

Constanti, P., \& Gibbs, P. (2004), "Higher education teachers and emotional labour" International Journal of Educational Management, 18 (4), 243-249.

Cordes, C. L., \& Dougherty, T. W. (1993). A review and an integration of research on job burnout. Academy of Management Review, 18(4), 621-656.

Gaan, N. (2012), "Impact of Emotional Labour on Teaching Effectiveness: A Study of Higher Education India", India Journal of Industrial Relations, 47 (4), 673-684.

Gosserand, H. R., \& Diefendorff, M. J. (2005). Emotional Display Rules and Emotional Labour: The Moderating Role of Commitment. Journal of Applied Psychology, 90(6), 1256-1264.

Grandey, Alicia A. (2000). "Emotion Regulation in the Workplace: A New Way to Conceptualize Emotional Labor." Journal of Occupational Health Psychology, 5(1), 95-110.

Grandey, A. A. (2003). When "the show must go on": Surface and deep acting as determinants of emotional exhaustion and Organizational consequences of emotional labour in mangenent peer-rated service delivery. Academy of Management Journal, 46, 86-96.

Gross, J. J. (1998). The emerging field of emotion regulation: An integrative review. Review of General Psychology, 2(3), 271-299.

Hall, C., Swart, W., \& Duncan, S. (2013), "Balancing Customer Needs and Standards in Higher Education," Quality Approaches in Higher Education, 3(1).

Hargreaves, A. (1998). The emotional practice of teaching. Teaching and Teacher Education, 14(8), 835-854. 
(2000). Mixed emotions: Teachers' perceptions of their interactions with students. Teaching and Teacher Education, 16, 811-826.

...(2001). Emotional geographies of teaching. Teaching and Teacher Education,14(8), 835-854.

Hayes, S., \& Kleiner, B. H. (2001) The managed heart: the commercialization of human feeling - and its danger, Management Research News, 24(3/4), 81-85.

Heskett, J., Sasser, Jr. W. E., \& Schlesinger, L. (1997). The Service Profit Chain: How Leading Companies Link Profit and Growth to Loyalty, Satisfaction, and Value. New York: Free Press, 1997.

Hochschild, A. R. (1983) The Managed Heart: Commercialization of Human Feeling. Berkeley: University of California Press.

Kahn, A. W. (1990). Psychological Conditions of Personal Engagement and Disengagement at Work. Academy of Management Journal, 33(4), 692-724.

Kim, H. J. (2008). Hotel service providers' emotional labor: The antecedents and effects on burnout. International Journal of Hospitality Management, 27, 151-161

Kinman, G., Wray, S., \& Strange, C. (2011): Emotional labour, burnout and job satisfaction in UK teachers: the role of workplace social support, Educational Psychology, 31(7), 843-856.

Karim, J. (2009). Emotional labor and psychological distress: Testing the mediatory role of work family conflict. European Journal of Social Sciences, 11, 584-598.

Lam, W., \& Chen, Z. (2012). "When I put on my service mask: Determinants and outcomes of emotional labor among hotel service providers according to affective event theory." International Journal of Hospitality Management 30: 3-11.

Lawrence, S., \& Sharma, U. (2002). "Commodification of education and academic labour-using the balanced scorecard in a university setting". Critical perspectives on accounting, 13(5), 661677.

Maslach, C. (1978). The client role in staff burn-out. Journal of Social Issues, 34(4), 111-124.

Maslach, C., Schaufeli, W. B., \& Leiter, M. P. (2001). Job burnout. Annual Review of Psychology, 52, 397-422.

Mann, S. (1997) "Emotional labour in organizations", Leadership \& Organization Development Journal, 18(1),4-12.

Montgomery, A. J., Panagopolou, E., de Wildt, M., \& Meenks, E. (2006). Work-family interference, emotional labor and burnout. Journal of Managerial Psychology, 21(1), 36-51.

Morris, J. A., \& Feldman, D.C. (1996), "The Dimensions, Antecedents and Consequences of Emotional Labor", Academy of Management Review, 21(4), 989-1010.

Nias, J. (1999). Teaching as a culture of care. In J. Prosser (Ed.), School Culture (pp. 66-81). London: Paul Chapman Pub.

Ogbonna, E., \& L.C. Harris. 2004. Work intensification and emotional labour among UK university lecturers: An exploratory study. Organization Studies, 25(7), 1185-203

Özdevecioğlu, M., \& Kanıgür, S. (2009). Çalışanlarin ilişki ve görev yönelimli liderlik algılamalarının performansları üzerindeki etkileri”, KMU İIBF Dergisi,11, 53-82.

Schaubroeck, J., \& Jones, J. R. (2000). Anecdotes of workplace emotional labour dimensions and moderators of their effects on physical symptoms, Journal of Organizational Behavior, 21,16383 .

Selvarajah, K., \& Sulaiman, S. (2014). The Effects of social media on Gen Z's Intention to Select Private Universities in Malaysia, Review of Integrative Business and Economics Research 3 (2), 466.

Selvarajah, K., \& Jaya, P. K. (2017). The effects of rmotional labor on private University Lecturers. Human Resource Management Research, 28-32.

Varca, P. E. (2009) "Emotional empathy and front-line employees: does it make sense to care about the customer?", Journal of Services Marketing, 23 (1), 51 - 56.

Wharton, A. (1993), "The effective consequences of service work: Managing emotions on the job", Work and Occupations, 20 (2), 205-32.

Ybema, J., \& P. Smulders. 2002. Emotionele belasting en de noodzaak tot het verbergen van emoties op het werk [Emotional demand and the need to hide emotions at work]. Gedrag en Organisatie, 15(3), 129-46. 
Zapf, D., Vogt, C., Seifert, C., Mertini, H., \& Isic, A. (1999). Emotion Work as a Source of Stress: The Concept and Development of an Instrument. European Journal of Work\& Organizational Psychology, 8 (3), 371-400.

Zapf, D. (2002). Emotion work and psychological well-being - a review of the literature and some considerations, Human Resource Management Review, 12(2), 237-68.

\section{APPENDIX}

Measurement Scales used for Data Collection

\section{Emotional Labour Scale (Brotheridge \& Lee, 1998)}

Duration

Intensity.

Variety.

EMOTIONAL LABOR AND BURNOUT

Surface Acting

Deep Acting

Emotion Work Requirements Scale (Best et al, 1997)

Requirement to Display Positive Emotions

Requirement to Hide Negative Emotions 